\title{
Chronic thromboembolic pulmonary hypertension in Austria and Japan
}

Stella Chausheva, MSc, ${ }^{\mathrm{a}}$ Akira Naito, MD, ${ }^{\mathrm{b}}$ Aiko Ogawa, MD, ${ }^{\mathrm{c}}$ Veronika Seidl, MSc, ${ }^{\mathrm{a}}$

Max-Paul Winter, MD, ${ }^{\text {a }}$ Smriti Sharma, MSc, ${ }^{\text {a }}$ Roela Sadushi-Kolici, MD, ${ }^{\text {a }}$

Ioana-Alexandra Campean, MD, ${ }^{\mathrm{a}}$ Shahroukh Taghavi, MD, ${ }^{\mathrm{d}}$ Bernhard Moser, MD, ${ }^{\mathrm{d}}$ Walter Klepetko, MD, ${ }^{\mathrm{d}}$

Keiichi Ishida, MD, ${ }^{\mathrm{e}}$ Hiromi Matsubara, MD, ${ }^{\mathrm{c}}$ Seiichiro Sakao, MD, ${ }^{\mathrm{b}}$ and Irene M. Lang, MD

\section{ABSTRACT}

Objective: Chronic thromboembolic pulmonary hypertension (CTEPH) is characterized by one or more of the following features: intraluminal thrombus organization, fibrous stenosis, and complete obliteration of major pulmonary arteries, amenable to significant improvement by pulmonary endarterectomy (PEA) or balloon pulmonary angioplasty, and medical treatments with vasodilators. Because treatment practices and outcomes differ in Europe versus Japan, we hypothesized that population-based characteristics of pulmonary vascular phenotypes may exist in Austria compared with Japan. The objectives of this study were to analyze clinical characteristics, hemodynamics, and PEA specimens in consecutive patients with CTEPH undergoing PEA in Austria and Japan.

Methods: Clinical features, hemodynamics, and PEA specimens were collected and analyzed in patients with CTEPH undergoing PEA, and clinical features and hemodynamics were collected and analyzed in patients with notoperated CTEPH and in patients with nonthromboembolic pulmonary arterial hypertension.

Results: Apart from key differences between Austrian and Japanese patients regarding body size, lung function vital capacity, cardiac output, and serum high-density lipoprotein levels, Austrian patients were more likely to be obese, have greater hematocrits and greater white blood cells counts, greater C-reactive protein levels, and significantly elevated serum myeloperoxidase levels compared with Japanese patients with CTEPH. Analysis of PEA specimens demonstrated more proximal thrombus and more fresh red thrombus components in Austrian patients.

Conclusions: This study documents an inflammatory thrombotic phenotype in Austrian compared with Japanese patients with CTEPH that may be a determinant of differential treatment outcomes. (J Thorac Cardiovasc Surg 2019;158:604-14)

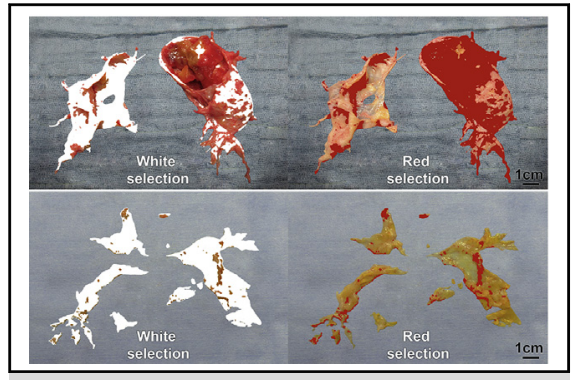

Typical pulmonary endarterectomy specimens from Austria (upper) and Japan (lower pane).

\section{Central Message}

Compared with Japanese, Austrian chronic thromboembolic pulmonary hypertension (CTEPH) is characterized by an inflammatory thrombotic phenotype.

\section{Perspective}

Our study compares disease characteristics of patients with chronic thromboembolic pulmonary hypertension in Austria and Japan. Our study documents an inflammatory thrombotic phenotype in Austrian compared with Japanese patients that may be accounted for by genetics, lifestyle, or environmental interactions and may be a determinant of differential treatment outcomes.

See Commentaries on pages 615 and 617.

\footnotetext{
From the Division of Cardiology, Departments of ${ }^{\text {a Internal Medicine II, and }}{ }^{\mathrm{d}}$ Thoracic Surgery, Vienna General Hospital, Medical University of Vienna, Vienna, Austria; ${ }^{\mathrm{b}}$ Departments of Respirology and ${ }^{\mathrm{e}}$ Cardiovascular Surgery, Graduate School of Medicine, Chiba University, Chiba, Japan; and ${ }^{\mathrm{c}}$ Department of Clinical Science, National Hospital Organization Okayama Medical Center, Okayama, Japan.

This study was supported by the Austrian Science Fund (SFB54).

Received for publication Oct 13, 2018; revisions received Dec 26, 2018; accepted for publication Jan 7, 2019; available ahead of print May 10, 2019.

Address for reprints: Irene M. Lang, MD, Division of Cardiology, Department of Internal Medicine II, Medical University of Vienna, Währinger Gürtel 18-20, 1090 Vienna, Austria (E-mail: irene.lang@meduniwien.ac.at).

$0022-5223 / \$ 36.00$

Copyright (c) 2019 by The American Association for Thoracic Surgery

https://doi.org/10.1016/j.jtcvs.2019.01.019
}

Chronic thromboembolic pulmonary hypertension (CTEPH) is a major vessel pulmonary artery disease characterized by intraluminal thrombus, flow-limiting fibrous webs, and complete obliteration of pulmonary arteries. Causes of disease are still unclear but specific risk factors

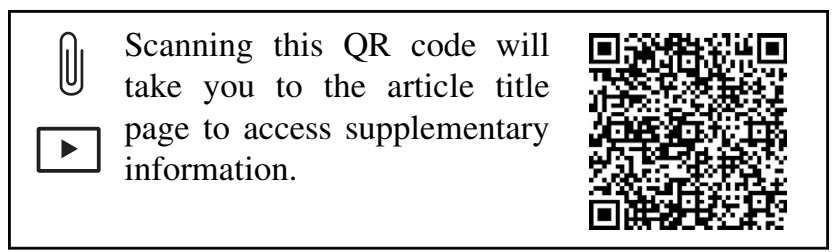




$\begin{array}{ll}\text { Abbreviations and Acronyms } \\ \text { BPA } & =\text { balloon pulmonary angioplasty } \\ \text { CTEPH } & =\text { chronic thromboembolic pulmonary } \\ & \text { hypertension } \\ \text { CV } & =\text { coefficient of variation } \\ \text { ELISA } & =\text { enzyme-linked immunosorbent assay } \\ \text { HDL } & =\text { high-density lipoprotein } \\ \text { IPAH } & =\text { idiopathic pulmonary arterial } \\ & \text { hypertension } \\ \text { MPO } & =\text { myeloperoxidase } \\ \text { NT-proBNP }= & \text { N-terminal pro b-type natriuretic } \\ & \text { peptide } \\ \text { PAH } & =\text { pulmonary arterial hypertension } \\ \text { PE } & =\text { pulmonary embolism } \\ \text { PEA } & =\text { pulmonary endarterectomy } \\ \text { RT } & =\text { room temperature } \\ \text { VTE } & =\text { venous thromboembolism }\end{array}$

have been identified, for example, previous pulmonary embolism (PE). The incidence of CTEPH in survivors of acute $\mathrm{PE}$ is about $3 \% .{ }^{1}$ In a 2009 population-based study, ${ }^{2}$ the reported rate of PE in Japan was 7 cases per 100,000 population per year, much lower than in the United States and Europe. ${ }^{3}$ Although the exact prevalence and annual incidence of CTEPH are unknown, ${ }^{4}$ the crude annual incidence of diagnosed PE and crude annual full (ie, diagnosed and undiagnosed) incidence of CTEPH in the United States and Europe were estimated as 66 to 104 and 3 to 5 cases per 100,000 population per year, whereas in Japan these rates were lower at 6.7 and 1.9 per 100,000 population, respectively. ${ }^{3}$ These data suggest that there may be intrinsic differences between races.

There exist high-quality registry data on different CTEPH patient populations. Median age of Austrian patients at diagnosis is 64.5 years; surgical cases are younger (57 years). ${ }^{5}$ In Europe, both sexes are equally affected, ${ }^{6}$ whereas in Japan, the female-to-male ratio is $2: 1 .^{7}$ In a recent substudy of the European CTEPH registry comparing 436 patients with CTEPH with 158 patients with idiopathic pulmonary arterial hypertension (IPAH) collected in the same centers, older age, history of acute venous thromboembolism (VTE), and blood groups non-O were independent risk factors for CTEPH. ${ }^{4}$ The gold-standard treatment for CTEPH is pulmonary endarterectomy (PEA), which carries a $2.2 \% 30$-day mortality in low-risk patients ${ }^{8}$ and excellent long-term survival in experienced centers (Video 1). ${ }^{9}$ Patients with CTEPH who are not treated are at risk of right heart failure, progressive pulmonary hypertension, and death. ${ }^{6}$ In the European registry, only $57 \%$ of patients underwent surgery. ${ }^{10}$ Inoperable patients or patients with recurrent pulmonary hypertension after PEA may be treated with riociguat, the only currently
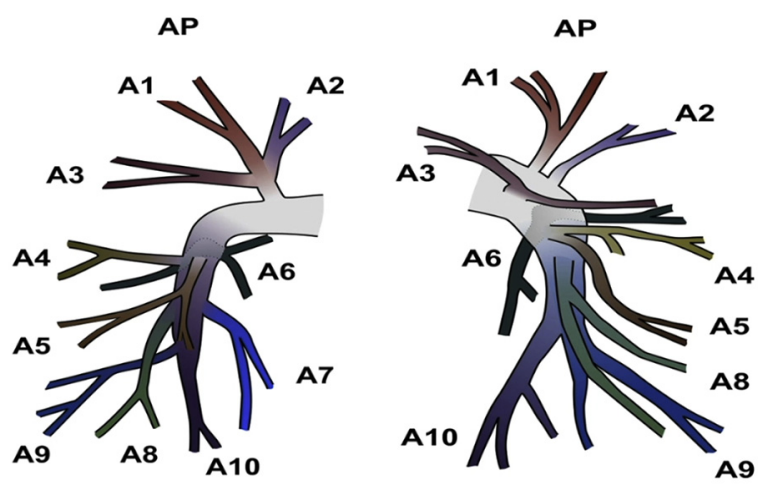

VIDEO 1. Pulmonary endarterectomy for chronic thromboembolic pulmonary hypertension (CTEPH). Video available at: https://www.jtcvs. org/article/S0022-5223(19)30071-6/fulltext.

approved medical treatment for $\mathrm{CTEPH},{ }^{11}$ or undergo balloon pulmonary angioplasty (BPA), a recently refined percutaneous interventional technique. ${ }^{12,13}$

Postoperative $\mathrm{PH}$ is commonly related to incomplete PEA and very rarely to recurrent PE. In Japan, only a small minority of patients undergo PEA; the majority of patients are treated outside of surgical centers with BPA. BPA leads to improvement in ejection fraction, right ventricular function, peak systolic strain, and hemodynamics. ${ }^{14-16}$ In Europe, BPA has gained ground, but results are still less favorable than in Japan. ${ }^{17}$ About $12 \%$ of Austrian patients with CTEPH suffer from concomitant coronary artery disease. ${ }^{10,18}$ Atherosclerotic vascular disease in European patients may be a disease-modifying factor in CTEPH.

Therefore, the purpose of our study was to understand population-based differences in CTEPH characteristics. We compared plasma and vascular tissues to assess (1) clinical risk factors, (2) hemodynamic markers of disease progression, (3) biochemical markers of inflammation, and (4) histopathology of PEA specimens from Austrian and Japanese patients with CTEPH.

\section{MATERIALS AND METHODS \\ Study Design}

This study was approved by the Ethics Committee of the Medical University of Vienna (approval number 2009/972 for blood sampling and approval number 220/2008 for tissue sampling), Chiba Institutional Review Board of Chiba University (approval number 353 [clot sampling] and 826 [research use of clinical data and serum]) and the National Hospital Organization Okayama Medical Center (H22-RINKEN-44). All patients provided written informed consent for participation in the study.

We studied consecutive patients with CTEPH undergoing PEA who were willing to participate in the study (20 each between January 2016 and March 2017 in the Vienna General Hospital, and between October 2012 and February 2015 in Chiba University Hospital), consecutive consentable not-operated patients with CTEPH (20 each between January 2016 and March 2017 in the Vienna General Hospital and between July 2014 and February 2017 in the National Hospital Organization Okayama Medical Center in Japan). Controls were consecutive patients with PAH (20 each in Austria and Japan, respectively). Operability is based on 
availability of PEA, technical feasibility, the medical risk/benefit ratio, and patient consent. Because operability is not an objective measure, patients undergoing PEA later were labeled as later-operated when their baseline data were considered, and those patients who did not undergo PEA were labeled as not operated within the time frame of the study.

All data were collected at the time of the baseline right heart catheterization, which has been arbitrarily labeled as the date of diagnosis in studies on CTEPH. ${ }^{10}$ Patient selection for PEA or BPA was accomplished by respective CTEPH teams and was based on the extent and most proximal location of obstructive material in relation to hemodynamic severity, parenchymal lung function, on age and co-morbidities, patient consent, and local expertise. Endarterectomy was bilateral, complete, through a median sternotomy, identifying the correct dissection plane under circulatory arrest supported by cooling to $18^{\circ} \mathrm{C}$ as described. ${ }^{19}$ Endarterectomy specimens were categorized after completion of the procedure. ${ }^{20}$

\section{Study Subjects}

Inclusion criteria. All candidates had to have been seen and diagnosed within the CTEPH centers of the participating institutions, have persistent symptoms despite optimal medical therapy, be $\geq 18$ years old, white if in Austria, and Japanese if in Japan. All patients had to provide written informed consent and had to be willing to comply with all clinical investigations and treatments.

Exclusion criteria. Subjects were excluded if they were on immunosuppression or systemic steroid treatment and had severe infection (eg, lung abscesses) or if there was not enough clot/serum available. Seven patients in Austria (Medical University of Vienna) and 3 patients in Japan (Chiba University) were excluded for one of these reasons.

\section{Diagnosis of CTEPH and PAH}

A diagnosis of CTEPH was made after at least 3 months of effective anticoagulation and based on an invasively measured mean pulmonary artery pressure $\geq 25 \mathrm{~mm} \mathrm{Hg}$, a mean pulmonary artery wedge pressure $\leq 15 \mathrm{~mm}$ $\mathrm{Hg}$ in the presence of at least one (segmental) perfusion defect detected by lung scanning/multidetector computed tomographic angiography and selective invasive pulmonary angiography. Diagnosis of PAH was according to the guidelines ${ }^{21}$ and was specified by a perfusion scan lacking segmental defects. Sex, age, weight and height, body mass index, modified World Health Organization functional class, 6-minute walking distance, and laboratory parameters were recorded (Tables 1 and 2). Waist circumferences were measured by computed tomography around the umbilicus.

\section{Laboratory Analyses and Specimen Analyses}

Blood samples "at diagnosis" were drawn into citrate and serum tubes and were obtained during the initial diagnostic right heart catheterization (always performed off PAH treatments, and vitamin K antagonist therapy was switched to low-molecular-weight heparin). Not-operated patients in Okayama Medical Center remained on warfarin or on direct oral anticoagulants. All later-operated patients were on vitamin $\mathrm{K}$ antagonist anticoagulation. In Austria, 18 patients with PAH were on oral anticoagulation, compared with only 1 patient with PAH in Japan.

PEA specimen pictures (Figure 3) were analyzed with TissueFAXS software (TissueGnostics GmbH, Vienna, Austria). To avoid sampling errors,

TABLE 1. Characteristics of patients with CTEPH who were later-operated

\begin{tabular}{|c|c|c|c|}
\hline & \multicolumn{2}{|c|}{ Later-operated CTEPH patients ( $N=20$ each) } & \multirow[b]{2}{*}{$P$ value } \\
\hline & Austria & Japan & \\
\hline Age, y & $59(49-67)$ & $66(60-70)$ & $.05^{*}$ \\
\hline Female, $\mathrm{n}$ & 9 & 18 & - \\
\hline Height, $\mathrm{cm}$ & $171.65 \pm 9.91$ & $153.7 \pm 8.2$ & $<.001 \dagger$ \\
\hline Body weight, kg & $75(70-96)$ & $48(45-52)$ & $<.001 *$ \\
\hline BMI, kg.m² & $25(24-30)$ & $21(19-22)$ & $<.001^{*}$ \\
\hline Systemic pressure systolic, $\mathrm{mm} \mathrm{Hg}$ & $138.8 \pm 26.4$ & $121.4 \pm 21.6$ & $.02 \dagger$ \\
\hline Systemic pressure diastolic, $\mathrm{mm} \mathrm{Hg}$ & $74.3 \pm 14.1$ & $72.9 \pm 13.6$ & $.73 \dagger$ \\
\hline Systemic pressure, mean, $\mathrm{mm} \mathrm{Hg}$ & $99.2 \pm 18.4$ & $90.1 \pm 20.2$ & $.14 \dagger$ \\
\hline Pulmonary artery pressure systolic, $\mathrm{mm} \mathrm{Hg}$ & $80.0 \pm 21.6$ & $74.5 \pm 19.2$ & $.39 \dagger$ \\
\hline Pulmonary artery pressure diastolic, $\mathrm{mm} \mathrm{Hg}$ & $24.0 \pm 9.1$ & $21.8 \pm 6.3$ & $.27 \dagger$ \\
\hline Pulmonary artery pressure, mean, $\mathrm{mm} \mathrm{Hg}$ & $42.0 \pm 2.0$ & $41.4 \pm 10.1$ & $.90 \dagger$ \\
\hline Cardiac index, $\mathrm{L} / \mathrm{min} / \mathrm{m}^{2}$ & $2.83 \pm 0.85$ & $2.89 \pm 0.70$ & $.81 \dagger$ \\
\hline Cardiac output, L/min & $5.86(4.2-6.5)$ & $4.0(3.6-5)$ & $.04 *$ \\
\hline Pulmonary vascular resistance, dyne.sec.cm ${ }^{-5}$ & $617 \pm 259$ & $680 \pm 294$ & $.48 \dagger$ \\
\hline $\mathrm{PaO}_{2}$ (room air), $\mathrm{mm} \mathrm{Hg}$ & $60.8 \pm 10.0$ & $56.2 \pm 8.3$ & $.12 \dagger$ \\
\hline Heart rate, beats/min & $75 \pm 15$ & $69 \pm 10$ & $.11 \dagger$ \\
\hline 6-MWD, m & $405 \pm 131$ & $384 \pm 76$ & $.56 \dagger$ \\
\hline $\mathrm{VC}, \mathrm{L}$ & $3.6(3-4.8)$ & $2.4(2-2.9)$ & $<.001 *$ \\
\hline$\% \mathrm{VC}$ & $94.4 \pm 19.0$ & $92.4 \pm 10.2$ & $.68 \dagger$ \\
\hline$\%$ FEV1.0 & $90(88-97)$ & $91(79-103)$ & $.98^{*}$ \\
\hline
\end{tabular}

Data are presented as mean \pm standard deviation or median (interquartile range), with differences in adjusted means and $95 \%$ confidence intervals. Nonparametric WilcoxonMann-Whitney $U$ test was used for non-normally distributed data and indicated with * symbols; independent samples $t$-test for normally distributed data are indicated with $\dagger$ symbols. All $P$ values $(P<.05)$ are exploratory. $C T E P H$, Chronic thromboembolic pulmonary hypertension; $B M I$, body mass index; $\mathrm{PaO}_{2}$, arterial partial pressure of oxygen; 6-MWD, 6-minute walking distance; $V C$, vital capacity; $F E V 1.0$, forced expiratory volume in 1 second. 
TABLE 2. Characteristics of patients with nonthromboembolic pulmonary hypertension

\begin{tabular}{|c|c|c|c|}
\hline & \multicolumn{2}{|c|}{ PAH patients } & \multirow[b]{2}{*}{$P$ value } \\
\hline & Austria & Japan & \\
\hline Age, y & $59(56-67)$ & $51(41-56)$ & $.19 *$ \\
\hline Female, $\mathrm{n}$ & 7 & 17 & - \\
\hline Height, $\mathrm{cm}$ & $168 \pm 9.60$ & $156 \pm 7.52$ & $<.001 \dagger$ \\
\hline Body weight, $\mathrm{kg}$ & $79 \pm 17$ & $56 \pm 10$ & $.01 \dagger$ \\
\hline BMI, kg.m² & $29(23-31)$ & $22(20-25)$ & $<.001 *$ \\
\hline Systemic pressure systolic, $\mathrm{mm} \mathrm{Hg}$ & $133 \pm 19$ & $115 \pm 19$ & $<.001 \dagger$ \\
\hline Systemic pressure diastolic, $\mathrm{mm} \mathrm{Hg}$ & $71.0 \pm 13.0$ & $68.0 \pm 13.0$ & $.09 \dagger$ \\
\hline Systemic pressure, mean, $\mathrm{mm} \mathrm{Hg}$ & $93.0 \pm 17.0$ & $86.0 \pm 17.0$ & $.02 \dagger$ \\
\hline Pulmonary artery pressure systolic, $\mathrm{mm} \mathrm{Hg}$ & $152.0 \pm 226$ & $69.0 \pm 18.0$ & $.04 \dagger$ \\
\hline Pulmonary artery pressure diastolic, $\mathrm{mm} \mathrm{Hg}$ & $39.2 \pm 29$ & $24.0 \pm 5.9$ & $.05 \dagger$ \\
\hline Pulmonary artery pressure, mean, $\mathrm{mm} \mathrm{Hg}$ & $50.0 \pm 20.0$ & $41.0 \pm 9.6$ & $.10 \dagger$ \\
\hline Cardiac index, $\mathrm{L} / \mathrm{min} / \mathrm{m}^{2}$ & $2.6 \pm 0.68$ & $3.0 \pm 0.9$ & $.23 \dagger$ \\
\hline Cardiac output, L/min & $5 \pm 1.1$ & $4.0 \pm 1.2$ & $.32 \dagger$ \\
\hline Pulmonary vascular resistance, dyne.sec.cm ${ }^{-5}$ & $711 \pm 512$ & $593 \pm 213$ & $.69 \dagger$ \\
\hline $\mathrm{PaO}_{2}$ (room air), $\mathrm{mm} \mathrm{Hg}$ & $65.0 \pm 10.0$ & $73.0 \pm 9.2$ & $.03 \dagger$ \\
\hline Heart rate, beats/min & $72 \pm 10$ & $68 \pm 13$ & $.14 \dagger$ \\
\hline 6-MWD, m & $398 \pm 127$ & $462 \pm 104$ & $.07 \dagger$ \\
\hline $\mathrm{VC}, \mathrm{L}$ & $3.5 \pm 0.9$ & $2.7 \pm 0.7$ & $.02 \dagger$ \\
\hline$\% \mathrm{VC}$ & $81.0 \pm 17.0$ & $92.0 \pm 14.0$ & $.06 \dagger$ \\
\hline$\%$ FEV1.0 & $79.6 \pm 16.0$ & $87.3 \pm 15$ & $.41 \dagger$ \\
\hline
\end{tabular}

Data are presented as mean \pm SD or median (interquartile range), with differences in adjusted means and $95 \%$ confidence intervals. Nonparametric Wilcoxon-Mann-Whitney $U$ test was used for non-normally distributed data and indicated with * symbols, independent samples $t$ test for normally distributed data are indicated with $\dagger$ symbols. All $P$ values $(P<.05)$ are exploratory. $P A H$, Pulmonary arterial hypertension; $B M I$, body mass index; $\mathrm{PaO}_{2}$, arterial partial pressure of oxygen; 6-MWD, 6-minute walking distance; $\mathrm{VC}$, vital capacity; FEVI.0, forced expiratory volume in 1 second.

the entirety of respective surgical specimens was assessed, analyzed with TissueFAXS, and red or white portions expressed as percentages of the whole. Total thrombus area was calculated based on Austrian and Japanese PEA specimen images with the scale bar measurement tool in ImageJ (National Institutes of Health, Bethesda, Md).

\section{Immunohistochemical Analysis}

Anti-CD68 (\#M0814; Dako, Cambridge, United Kingdom) and antiCD31 antibodies (\#M0823; Dako) were used for immunohistochemistry. A Histostain-Plus IHC kit (\#859043; Thermo Fisher Scientific, Waltham, Mass) was used in the labeled-[strept]Avidin-Biotin technique. Sections $(3 \mu \mathrm{m})$ were blocked and then incubated with primary antibodies diluted in phosphate-buffered saline for 1 hour at room temperature (RT). A secondary antibody was used for 10 minutes at RT. Sections were treated with enzyme conjugate (10 minutes at RT), followed by the substratechromogen mixture (aminoethylcarbazole) 3 to 5 minutes at RT. The chromogen produces a red reaction product at immune-positive sites. Slides were washed and stained with hematoxylin and mounted in Aquatex (aqueous mounting agent) for microscopy (\#108562; Merck KGaA, Darmstadt, Germany).

\section{Histologic Analysis}

For histochemical analyses, a modified trichrome stain was used. ${ }^{22}$ Early fibrin and red blood cells are shown by lissamine fast yellow, mature fibrin by a combination of acid fuchsin, Biebrich scarlet, and ponceau $2 \mathrm{R}$ (red), collagen appears green. All slides were analyzed with TissueFAXS software.

\section{Specimens and Sample Preparation and Laboratory Analyses}

Surgical PEA specimens were immediately fixed in $7.5 \%$ (in Austria) or $10 \%$ (in Japan) buffered formaldehyde, and a representative portion was frozen in liquid nitrogen and stored at $-80^{\circ} \mathrm{C}$. Total cholesterol, total triglycerides, high-density lipoprotein (HDL) cholesterol, and lowdensity lipoprotein cholesterol were measured by enzymatic assays (CHOD-PAP, GPO-PAP). C-reactive protein, albumin, and lipoprotein (a) were detected by immunoturbidimetric test. Myeloperoxidase (MPO) levels in serum were measured by Human MPO Instant ELISA Kit (BMS2038INST; Thermo Fisher Scientific). Standard curves and sample concentrations were calculated based on the mean of duplicates for each dilution or sample. Anti-cardiolipin and anti-beta-2 glycoprotein $\operatorname{IgM}$ and $\operatorname{IgG}$ antibodies $(\mathrm{U} / \mathrm{mL}$ ) were measured by enzyme-linked immunosorbent assay (ELISA) in serum samples from later-operated Austrian and Japanese patients. Protein S was measured using a coagulometric method. Protein $\mathrm{C}$ activity was determined by chromogenic assay. The latex agglutination test was used to measure D-dimer. Beta 2 microglobulin was detected by nephelometry. The overall mean \pm standard deviation of the intra-assay coefficient of variation $(\mathrm{CV})$ was $1.93 \pm 1.08$. The overall interassay $\mathrm{CV}$ varied from $1.3 \%$ to $4.10 \%$, for the MPO ELISA it was $6.2 \%$ (Human MPO ELISA, Product information and manual; Thermo Fisher Scientific).

$\mathrm{N}$-terminal pro b-type natriuretic peptide (NT-proBNP) was routinely measured by ELISA in serum samples from Austrian patients. The CV was $3.7 \%$, and the normal range 0 to $125 \mathrm{pg} / \mathrm{mL}$. In Japan, BNP measurements were performed with an assay by Abbott Japan Co. Ltd (Tokyo, 
TABLE 3. Laboratory parameters of patients with CTEPH who were later-operated

\begin{tabular}{|c|c|c|c|}
\hline & \multicolumn{2}{|c|}{$\begin{array}{l}\text { later-operated CTEPH } \\
\text { patients }(N=20 \text { each })\end{array}$} & \multirow{2}{*}{$\begin{array}{c}P \\
\text { value }\end{array}$} \\
\hline & Austria & Japan & \\
\hline WBC, G/L & $6.9(16.1-8.2)$ & $5.7(5.0-6.8)$ & $<.001^{*}$ \\
\hline $\mathrm{RBC}, 10 * 4 / \mu \mathrm{L}$ & $5.2(4.3-5.2)$ & $4.3(4-4.4)$ & $<.001^{*}$ \\
\hline $\mathrm{Hb}, \mathrm{g} / \mathrm{dL}$ & $15.9(12.3-15.8)$ & $13.1(11.6-13)$ & $.02 *$ \\
\hline Platelets, G/L & $243(184-282)$ & $252(198-294)$ & $.83^{*}$ \\
\hline Triglycerides, mg/dL & $121(86-131)$ & $100(86-140)$ & $.98 *$ \\
\hline Total cholesterol, $\mathrm{mg} / \mathrm{dL}$ & $178.5 \pm 56.6$ & $199.7 \pm 30.5$ & $.15 \dagger$ \\
\hline HDL cholesterol, $\mathrm{mg} / \mathrm{dL}$ & $47.6 \pm 16.0$ & $68.0 \pm 11.5$ & $<.001 \dagger$ \\
\hline LDL cholesterol, mg/dL & $102.2 \pm 47.7$ & $109.6 \pm 30.5$ & $.55 \dagger$ \\
\hline GOT, U/L & $31(24-46)$ & $22(18-28)$ & $<.001 *$ \\
\hline GPT, U/L & $41(23-56$ & $17(12-22)$ & $<.001 *$ \\
\hline Albumin, $\mathrm{g} / \mathrm{dL}$ & $4(4-4.5)$ & $4(3.8-4.3)$ & $.66^{*}$ \\
\hline Uric acid, mg/dL & $6.4 \pm 1.7$ & $5.1 \pm 1.7$ & $.01 \dagger$ \\
\hline ProBNP, pg/mL & $1455(352-1921)$ & $689(457-2220)$ & $.46^{*}$ \\
\hline D-dimer, $\mu \mathrm{g} / \mathrm{mL}$ & $0.15(0.4-3.6)$ & $0.3(0.2-0.67)$ & $.16^{*}$ \\
\hline Creatinine, $\mathrm{mg} / \mathrm{dL}$ & $1.08(0.92-1.26)$ & $0.68(0.62-0.78)$ & $<.001^{*}$ \\
\hline
\end{tabular}

Data are presented as mean \pm standard deviation or median (interquartile ranges), with differences of adjusted means and $95 \%$ confidence intervals. Nonparametric Wilcoxon-Mann-Whitney $U$ test was used for non-normally distributed data, indicated with * symbol, independent samples $t$ test for normally distributed data, indicated with $\dagger$ symbols. All $P$ values $(P<.05)$ are exploratory. CTEPH, Chronic thromboembolic pulmonary hypertension; $W B C$, white blood cells; $R B C$, red blood cells; $H b$, hemoglobin; $H D L$, high-density lipoprotein; $L D L$, low-density lipoprotein; $G O T$, glutamate oxaloacetate transaminase; $G P T$, glutamate pyruvate transaminase; ProBNP, pro-brain natriuretic peptide.

Japan); assay variation was 5.8 to $14510 \mathrm{pg} / \mathrm{mL}$, the normal reference range was below $18.4 \mathrm{pg} / \mathrm{mL}$. BNP values were converted to NT-proBNP levels in $\mathrm{pg} / \mathrm{mL}$ using the formula NT-proBNP $=\mathrm{BNP} \times 8.56+91.7 .^{23}$

\section{Statistical Analysis}

Gaussian distributions were analyzed by Shapiro-Wilk test. Normally distributed variables including patient characteristics and histologic assessments were expressed as mean with standard deviation (mean \pm standard deviation). Continuous variables between the 2 groups were compared using the independent sample $t$ test. Non-normally distributed data are described as median and interquartile range, and the Wilcoxon-MannWhitney $U$ test was used for continuous non-normally distributed variables. Data were analyzed with SPSS Statistics version 22 (IBM Corp, Armonk, NY). A $P$ value $\leq .05$ was considered significant.

\section{RESULTS}

\section{Patient Characteristics}

Patient characteristics at the time of diagnosis are detailed in Tables 1 and 2. As expected, there was sex equipoise in Austrian patients with CTEPH, whereas female patients predominated all Japanese groups.

Age at diagnostic right heart catheterization, which was labeled as the date of diagnosis, was not significantly different between later-operated Austrian and Japanese patients (median 59 [49-67] years vs 66 [60-70] years, $P=.05)$, and not-operated Austrian and Japanese patients
TABLE 4. Laboratory parameters of patients with nonthromboembolic pulmonary hypertension

\begin{tabular}{|c|c|c|c|}
\hline & \multicolumn{2}{|c|}{ PAH patients } & \multirow{2}{*}{$\begin{array}{c}P \\
\text { value }\end{array}$} \\
\hline & Austria & Japan & \\
\hline WBC, G/L & $7.9 \pm 2.6$ & $5.3 \pm 1.6$ & $<.001 *$ \\
\hline $\mathrm{RBC}, 10 * 4 / \mu \mathrm{L}$ & $4.6(4.5-5)$ & $4.3(4.2-4.9)$ & $.05 \dagger$ \\
\hline $\mathrm{Hb}, \mathrm{g} / \mathrm{dL}$ & $13.8(14.0-16.0)$ & $12.6(13.5-15.0)$ & $.14 \dagger$ \\
\hline Platelet, G/L & $225 \pm 60$ & $274 \pm 38$ & $.10^{*}$ \\
\hline Triglycerides, mg/dL & $125(83-180)$ & $113(93-185)$ & $.95 \dagger$ \\
\hline Total cholesterol, mg/dL & $180.0 \pm 50.0$ & $183.0 \pm 31.0$ & $.95^{*}$ \\
\hline HDL cholesterol, mg/dL & $52.0 \pm 14.0$ & $60.0 \pm 19.0$ & $.24^{*}$ \\
\hline LDL cholesterol, $\mathrm{mg} / \mathrm{dL}$ & $108.0 \pm 36.0$ & $94.0 \pm 30.0$ & $.27 *$ \\
\hline GOT, U/L & $29(25-31)$ & $18(15-21)$ & $<.001 \dagger$ \\
\hline GPT, U/L & $23(17-31)$ & $13(10-16)$ & $<.001 \dagger$ \\
\hline Albumin, g/dL & $4.1 \pm 0.4$ & $4.1 \pm 0.3$ & $.66^{*}$ \\
\hline Uric acid, $\mathrm{mg} / \mathrm{dL}$ & $6.4(5.7-8.5)$ & $4.6(5.5-6.5)$ & $.01 \dagger$ \\
\hline ProBNP, pg/mL & $928(119-3041)$ & $207(60-643)$ & $.07 \dagger$ \\
\hline D-dimer, $\mu \mathrm{g} / \mathrm{mL}$ & $0.22(0.24-1.33)$ & $0.25(0.2-0.4)$ & $.43 \dagger$ \\
\hline Creatinine, $\mathrm{mg} / \mathrm{dL}$ & $1.05 \pm 0.27$ & $0.69 \pm 0.10$ & $<.001 *$ \\
\hline
\end{tabular}

Data are presented as mean \pm standard deviation or median (interquartile ranges), with differences of adjusted means and $95 \%$ confidence intervals. Nonparametric Wilcoxon-Mann-Whitney $U$ test was used for non-normally distributed data, indicated with $\dagger$ symbol, independent samples $t$ test for normally distributed data, indicated with * symbol, all $P$ values $(P<.05)$ are exploratory. $P A H$, Pulmonary arterial hypertension; $W B C$, white blood cells; $R B C$, red blood cells; $H b$, hemoglobin; $H D L$, high-density lipoprotein; $L D L$, low-density lipoprotein; $G O T$, glutamate oxaloacetate transaminase; GPT, glutamate pyruvate transaminase; ProBNP, pro-brain natriuretic peptide.

(median 63 [54-73] years vs $68[58-73]$ years, $P=.44$ ). No differences were observed between later-operated and not-operated Austrian patients (59 [49-67] vs 63 [54-73] years, $P=.19)$ and later-operated versus not-operated Japanese patients (66 [60-70] vs 68 [58-73] years $P=.12$ ). Austrian patients with PAH were older than Japanese patients with PAH (median 59 [56-67] years ${ }^{24}$ vs 51 [41-56] years, $P=.19)$. Respective subset diagnoses were IPAH $(\mathrm{n}=16)$ and connective tissue-associated PAH $(\mathrm{n}=4)$ in Austria, and IPAH $(\mathrm{n}=16)$, heritable PAH $(\mathrm{n}=6)$, and associated PAH $(\mathrm{n}=3)$ in Japan.

Austrian patients with CTEPH were taller and heavier than Japanese patients (Table 1), with larger waist circumferences (Austrian $100 \pm 11 \mathrm{~cm}$ vs Japanese $70 \pm 7.4 \mathrm{~cm}$, $P<.05$ ). Waist circumferences in female Austrian were $99.1 \pm 12 \mathrm{~cm}$ vs $70 \pm 7.8 \mathrm{~cm}$ in female Japanese patients with CTEPH, and $101 \pm 11 \mathrm{~cm}$ in male Austrian versus $71 \pm 1.7 \mathrm{~cm}$ in male Japanese patients with CTEPH $(P<.05)$.

Cardiac output was greater in Austrians, and vital capacity was larger in Austrians, but not statistically different when indexed. Systemic systolic pressure was greater in later-operated Austrian and patients with PAH than in the respective Japanese. Right heart hemodynamics did not differ between Austrian and Japanese patients. 

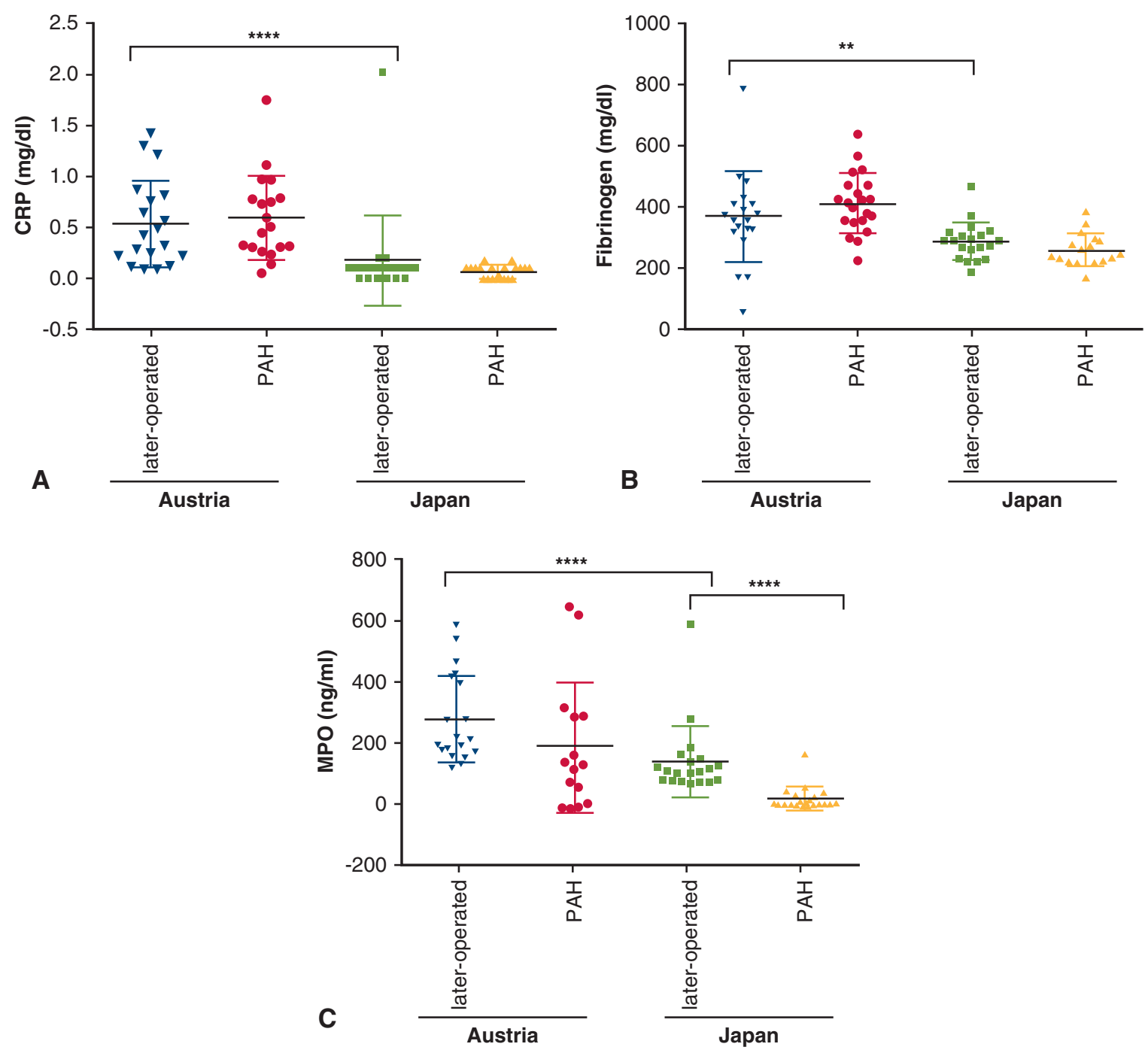

FIGURE 1. Plasma concentrations of CRP (A), fibrinogen (B), and serum MPO (C) in later-operated patients with chronic thromboembolic pulmonary hypertension and in PAH from Austria and Japan. Data are analyzed by nonparametric Wilcoxon-Mann-Whitney $U$ test compare differences between 2 independent groups, $* * P \leq .01 ; * * * P \leq .0001$. $C R P$, C-reactive protein; $P A H$, pulmonary arterial hypertension; $M P O$, myeloperoxidase.

No difference was observed in 6-minute walking distance between later-operated Austrian and Japanese patients, but a significant difference was observed between not-operated Austrian and not-operated Japanese patients $(468 \pm 141 \mathrm{~m}$ vs $274 \pm 110 \mathrm{~m}, P<.05$, Table E1).

\section{CTEPH Risk Factors}

All later-operated patients with Austrian with CTEPH versus $80 \%$ of later-operated patients with Japanese with CTEPH were carriers of a non-O blood group, compared with $70 \%$ of not-operated Austrian versus $80 \%$ of notoperated patients with Japanese. Eleven later-operated Austrian versus 4 later-operated Japanese patients with CTEPH had a history of PE, compared with 18 notoperated Austrian versus 7 not-operated Japanese patients.

\section{Laboratory Parameters}

Laboratory parameters at the time of diagnosis are detailed in Tables 3 and 4. Later-operated Austrian patients with CTEPH had greater white blood cell counts, red blood cells counts, hemoglobin levels (Tables 3 and 4), and also greater hematocrits compared with later-operated Japanese patients $(41.6 \pm 6.2 \%$ vs $38 \pm 5.7 \%, P=.04)$. There were no differences in arterial oxygen saturations (Tables 1 and 2).

Serum lipids were not different between groups, with the exception of HDL-cholesterol, which was greater in Japanese patients, both in later-operated and not-operated subjects (Table E2), but not in the nonthromboembolic PAH subset. Lipoprotein (a) levels were greater in Austrian later-operated patients than in Japanese later-operated patients (median 22.5 [5-137] $\mathrm{mg} / \mathrm{dL}$ vs 13.5 [4-143] $\mathrm{mg} / \mathrm{dL}, P=.07)$. 
One further disease-specific feature was the elevation of transaminases in Austrian patients with CTEPH. No differences were observed regarding the levels of protein $\mathrm{C}$ and $\mathrm{S}$ activities, antiphospholipid antibodies (1 carrier of anti-cardiolipin $\operatorname{IgG}$ and $\operatorname{IgM}$ antibodies in Austria vs 1 in Japan). One patient was carrier of $\beta_{2}$-glycoprotein $\mathrm{IgG}$ antibodies $(\mathrm{U} / \mathrm{mL})$ in Japan, compared with no such patient in Austria. One patient in Austria carried $\beta_{2}$-glycoprotein IgM antibodies $(\mathrm{U} / \mathrm{mL})$, compared with no Japanese patient. Although D-dimer levels were elevated above normal values in CTEPH without statistical significance, levels of C-reactive protein $(0.5 \pm 0.42 \mathrm{mg} / \mathrm{dL}$ vs $0.17 \pm 0.43 \mathrm{mg} / \mathrm{dL})$, fibrinogen $(369 \pm 150 \mathrm{mg} / \mathrm{dL}$ vs $288.8 \pm 61.80 \mathrm{mg} / \mathrm{dL})$, and MPO $(414 \pm 207 \mathrm{ng} / \mathrm{mL}$ vs $112 \pm 424 \mathrm{ng} / \mathrm{mL}$ ) were significantly greater in Austrian later-operated patients with CTEPH (Figure 1). Levels of $\beta_{2}$-microglobulin were $2.05 \pm 0.73 \mathrm{mg} / \mathrm{L}$ compared with $2.46 \pm 0.86 \mathrm{mg} / \mathrm{L}$ in later-operated Austrian versus Japanese patients $(P=\mathrm{ns})$.

Levels of serum immunoglobulins were $1204 \pm 265.3 \mathrm{mg} / \mathrm{dL}(\mathrm{IgG}), 242 \pm 83.8 \mathrm{mg} / \mathrm{dL}(\operatorname{IgA})$, and $121.3 \pm 54 \mathrm{mg} / \mathrm{dL}(\operatorname{IgM})$ in later-operated Austrian patients, compared with $1104 \pm 337 \mathrm{mg} / \mathrm{dL}$ (IgG), $338.9 \pm 450.8 \mathrm{mg} / \mathrm{dL}(\operatorname{IgA})$, and $99.6 \pm 45.9 \mathrm{mg} / \mathrm{dL}$ $(\operatorname{IgM})$ in later-operated Japanese patients $(P=.30, .35$, .17 , respectively).

\section{PEA Specimens}

Surgical classification demonstrated more type 2 disease in Austrians, and more type 3 disease in Japanese patients (Figure 2). Total thrombus area was larger in lateroperated Austrian patients than Japanese patients, without statistical significance $\left(18 \mathrm{~cm}^{2}\right.$ [14-26] compared with $16.3 \mathrm{~cm}^{2}$ [12-29], $P=.59$ ), and thrombus appeared thicker (Figure 3, A, compared with Figure 3, B). Figure 3, C,

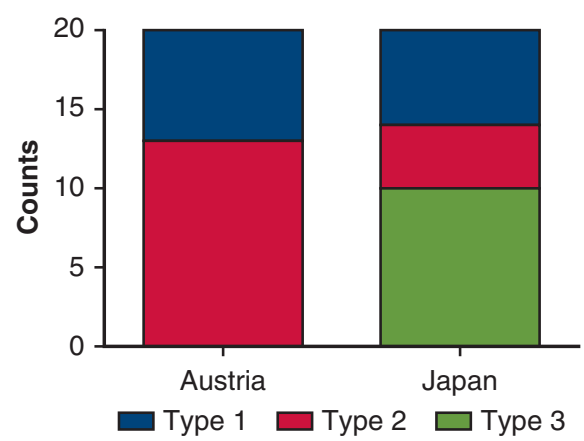

FIGURE 2. Surgical pulmonary endarterectomy specimens were categorized according to Thistlethwaite and colleagues. ${ }^{20}$ Type 1 classifies fresh thrombus in main-lobar arteries. Type 2 disease represents organized thrombus and intimal thickening proximal to segmental arteries, type 3 disease classifies intimal thickening-fibrosis in distal segmental arteries, and type 4 disease classifies distal arteriolar vasculopathy with removal of the intimal layer and no intraluminal disease. illustrates a systematic analysis of red and white thrombus. Red thrombus area as a proportion of total thrombus area was larger in Austrian patients, whereas the proportion of white thrombus area was larger in Japanese patients. Figure 4 illustrates histologic analysis and confirms significantly more red "fresh" thrombus area in Austrian specimens, compared with "white." This observation was also made on a histological level.

Numbers and distributions of tissue macrophages (Figure 4, D-F), or endothelial cells (Figure 4, G-I) were the same in PEA specimens from Austrians and Japanese.

\section{DISCUSSION}

CTEPH is a distinct obstructive pulmonary vascular condition amenable to successful treatment by PEA. However, because of technical complexity (only $10 \%$ of patients present with proximal major vessel obstructions), patient refusal, lack of expertise, and negative risk-benefit ratios, about $50 \%$ of patients remain unoperated in Europe. Recently, 3 treatment options have become available for patients with CTEPH and evolve to be complementary ${ }^{25}$ : PEA, BPA, and medical therapy. CTEPH treatment strategies vary significantly in Europe and Japan. Although there are currently 1.7 PEAs per million of population performed in Europe annually, compared with 0.9 in the United States, only 30 to 40 PEAs are performed annually in Japan, accounting for 1 PEA per billion.

By contrast, BPA experience is advanced in Japan, ${ }^{16}$ whereas it is still evolving in Europe. ${ }^{17}$ Because CTEPH is a thromboembolic condition, and incidence of pulmonary thromboembolism differs significantly between Europe and Japan (1500 in Europe vs 28-32 new patients in Japan per $1,000,000$ people per year), ${ }^{26,27}$ and results of treatments differ in Europe versus Japan, ${ }^{16}$ we analyzed in-depth differences in pulmonary vascular phenotypes between Austrian and Japanese patients with CTEPH. One Austrian CTEPH center, and 2 Japanese centers (one predominantly experienced in PEA and one predominantly experienced in BPA) contributed patients.

The main focus of this study was on patients undergoing PEA surgery in both geographic regions, providing access to vascular tissues. Main features of PAH, as opposed to $\mathrm{CTEPH}$, are negative ventilation-perfusion scintigram and lack of association with VTE, as well as general diseasespecific characteristics such as greater diastolic pressure, greater pulmonary vascular resistance, and greater arterial partial pressure of oxygen.

Median age of Austrian patients with CTEPH was 63 years, compared with 57 years of Japanese patients. As reported in the European CTEPH registry, ${ }^{10}$ both lateroperated Austrian and Japanese patients with CTEPH tended to be younger than not-operated patients.

As previously reported, ${ }^{28}$ female patients were more often affected in Japan, whereas sex equipoise was observed 

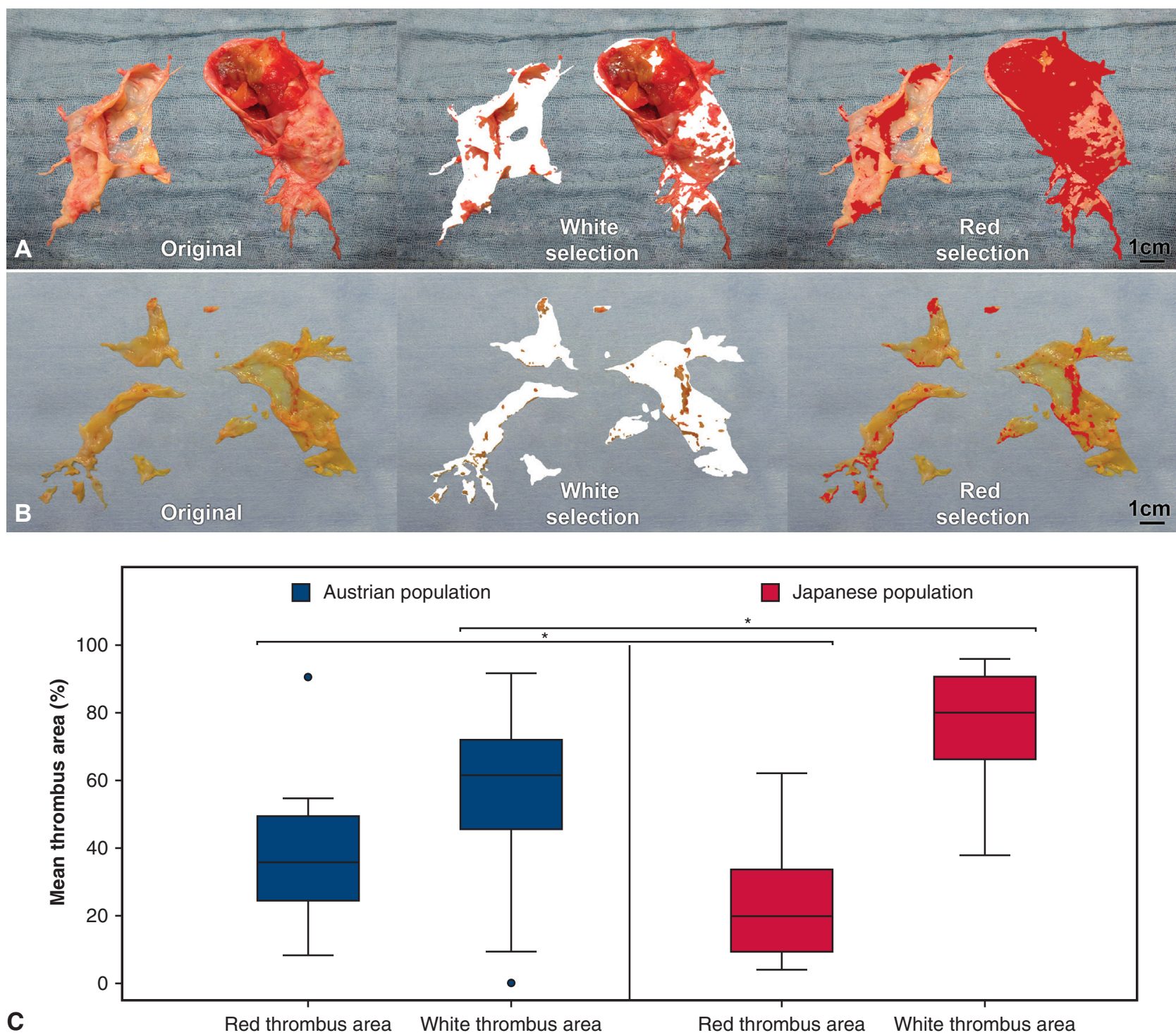

FIGURE 3. Analyses of red and white portions of PEA specimens from a representative Austrian patient (A) and a representative Japanese patient (B). Note that the Japanese thrombus tissue is thinner than the Austrian thrombus tissue. Austrian PEA specimen areas (blue, $\mathrm{n}=20)$ and Japanese PEA specimen areas $(r e d, n=20)$ are presented as percentage of red and white in relation to total thrombus area (C). The upper and lower borders of the box represent the upper and lower quartiles. The middle horizontal line represents the median. The upper and lower whiskers represent the maximum and minimum values of nonoutliers. Extra dots represent outliers. Data are analyzed by nonparametric Wilcoxon-Mann-Whitney $U$ test, ${ }^{*} P<.05$.

in Austrian CTEPH. Key differences between Austrian and Japanese patients were simple anthropomorphic parameters, including, for example, body size, lung function vital capacity, and invasively measured cardiac output. Although NT-proBNP levels were greater in Austrian patients, pulmonary hemodynamics were the same. A history of PE was more common in Austrian than Japanese patients, including previous massive PE in later-operated patients. Of course, these data are limited by the difficulty to differentiate acute PE from CTEPH on first presentation. ${ }^{29}$ Not-operated patients had more comorbidities. ${ }^{30}$
Laboratory analyses illustrated greater blood cell counts, hematocrit, and white blood cell counts in later-operated Austrian patients. Transaminases were greater in Austrian patients with CTEPH, whereas serum HDL was lower, which is in agreement with major differences in Austrian versus Japanese diets, and a metabolic syndrome phenotype in Austrian patients with CTEPH, including greater systolic blood pressure and increased waist circumferences in the later-operated Austrian versus Japanese group. Eleven Austrian patients with CTEPH were obese (body mass index >30), compared with 1 Japanese patient with CTEPH, 

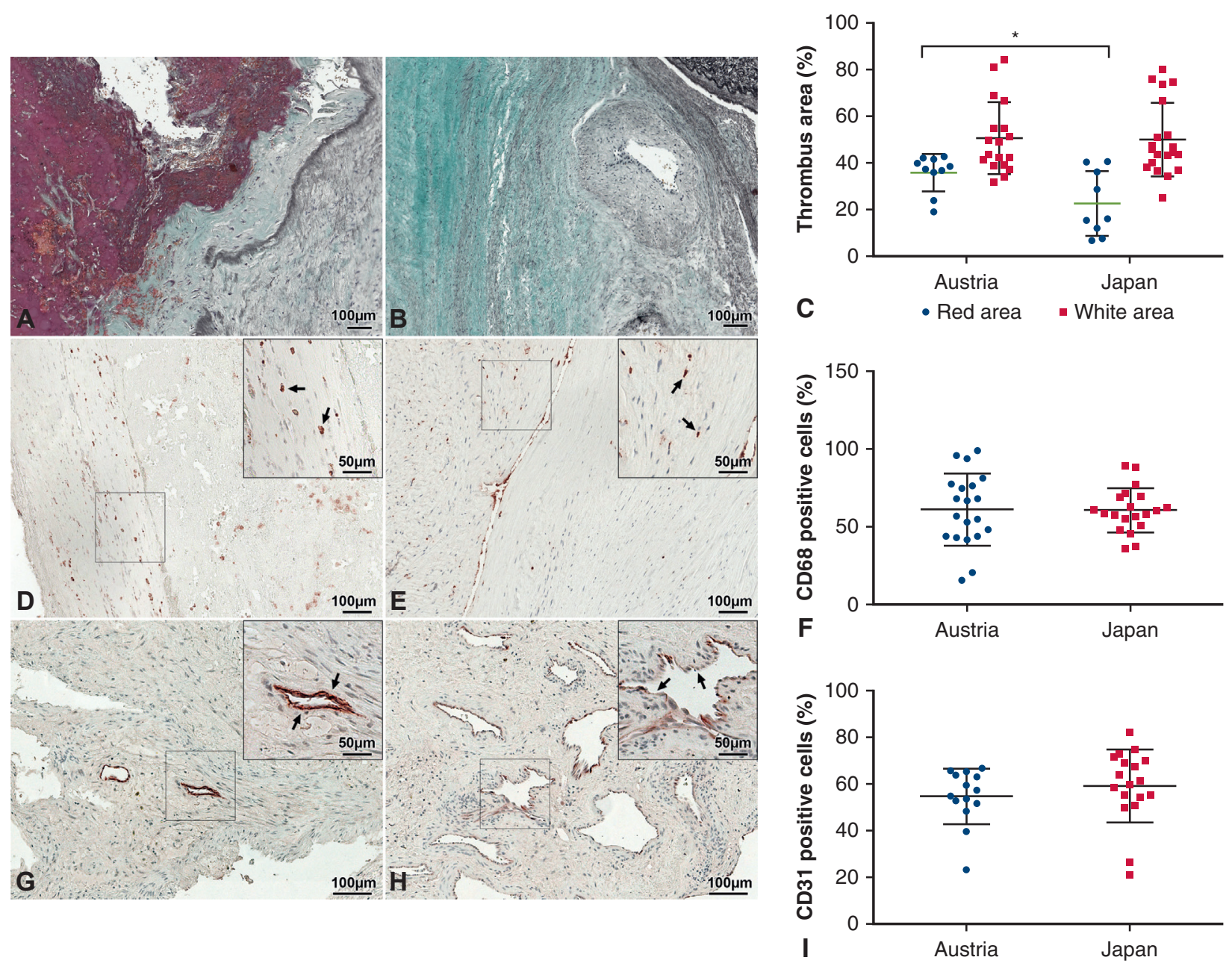

FIGURE 4. Trichrome stains from a representative Austrian (A, D, and G) and representative Japanese patient (B, E, and H). Early fibrin and red blood cells are shown by lissamine fast yellow, mature fibrin by a combination of acid fuchsin, Biebrich scarlet and ponceau 2R (blue), collagen appears blue. C, Quantification of red (fresh) thrombus area and green (collagen-rich) thrombus area. Macrophages (examples marked by black arrows in the inset magnification) are shown in D and E. Endothelial cells (examples marked by black arrows in the inset magnification) are shown in G and H. F and I, Quantification of macrophages and endothelial cells (expressed as number of CD68-positive cells or number of CD31-positive cells per high power field, respectively) in Austrian (round symbols) and Japanese patients (squares). Scale bars represent $100 \mu \mathrm{m}$. Respective high-power field images show scale bars representing $50 \mu \mathrm{m}$. All data were based on TissueFAXS quantification and analyzed by nonparametric Wilcoxon-Mann-Whitney $U$ test, $* P<.05$.

which may represent an additional disease component of Austrian CTEPH, ${ }^{31}$ presumably not impacting outcomes.

C-reactive protein was elevated in plasma of Austrian patients with CTEPH and PAH and has been implicated in CTEPH pathogenesis. ${ }^{18,32}$ Serum MPO was increased in patients with CTEPH only, suggesting a disease-specific inflammatory signal. MPO is most abundantly expressed in neutrophil granulocytes and produces hypochlorous acid from hydrogen peroxide during the neutrophil respiratory burst, degranulation, and neutrophil extracellular trap formation as part of antimicrobial activity. This observation is of interest because previous data from our group have demonstrated a role of staphylococcal infection in the pathogenesis of CTEPH in Austrian patients. ${ }^{33}$ The observation that the Austrian-Japanese gradient of MPO expression is only observed in CTEPH and not in patients with PAH speaks to MPO as disease biomarker. Another important observation is shown in Figure 2. Analyses of PEA specimens illustrate more central disease in Austrian patients and more distal disease in Japanese, which may account for less surgical accessibility in Japanese patients, thus impacting treatment decisions and outcomes.

\section{Limitations}

Numbers were limited by the low frequency of Japanese PEA, and therefore power may have been lacking to detect some differences. Hemodynamics were only measured at rest. Study controls were patients with 
nonthromboembolic PAH with subsets that differed in Austria compared with Japan, with Austrian patients being elderly like European patients. ${ }^{24}$ Austrian patients with CTEPH may be regarded as representative for European patients with CTEPH,${ }^{34}$ but this question was not addressed in the present work. MPO is in association with vascular disease in general. ${ }^{35}$ Size differences of PEA dissectates were based on 2-dimensional images and not on specimen weights or 3-dimensional reconstructions. Differences in geographic anticoagulation efficiencies were not systematically assessed, but generally lower international normalized ratios in Japanese patients would have suggested fresher thrombus than was observed. Furthermore, Austrian surgeons have many years of experience with PEA, whereas PEA is less established in Japan, which could possibly explain a difference in the nature and size of specimens retrieved at operation. Nevertheless, red thrombus is far easier to retrieve than white thrombus, which is more tightly attached to the pulmonary artery wall.

\section{CONCLUSIONS}

This study documents an inflammatory thrombotic phenotype in Austrian compared with Japanese patients with CTEPH (Graphical Abstract) that may account for differential success rates of interventional treatments. Furthermore, these differences may impact the differences in the incidences of VTE between the 2 populations in general.

\section{Conflicts of Interest Statement}

Akira Naito reports that he is a member of the Joint Collaborative Department with Teijin Pharma, Ltd, Japan and Ono Pharmaceutical, Ltd, Japan. Aiko Ogawa reports personal fees from Actelion Pharmaceuticals Japan Ltd, personal fees from Nippon Shinyaku Co, Ltd, and personal fees from Pfizer Japan Inc. Roela Sadushi-Kolici reports personal fees and other from Actelion, personal fees from AOP Orphan Pharmaceuticals, nonfinancial support and other from Bayer-Schering, nonfinancial support from GlaxoSmithKline, and other from SciPharm Sarl, outside the submitted work. Seiichiro Sakao received honoraria for lectures from Nippon Shinyaku Co, Ltd, Bayer, Actelion Pharmaceuticals, and Pfizer. Hiromi Matsubara reports personal fees from Actelion Pharmaceuticals Japan, Ltd, personal fees from AOP Orphan Pharmaceuticals AG, personal fees from Bayer Yakuhin, Ltd, personal fees from Pfizer Japan, Inc, personal fees from Nippon Shinyaku, Co, Ltd, and personal fees from Kaneka Medix Corporation. Irene M. Lang reports grants and personal fees from Actelion and grants and personal fees from AOP Orphan. All other authors have nothing to disclose with regard to commercial support.
We thank Prof Koichiro Tatsumi, Prof Nobuhiro Tanabe, Dr Takayuki Jujo, Department of Respirology, and Prof Goro Matsumiya, Department of Cardiovascular Surgery, Graduate School of Medicine, Chiba University for tissue sample collection.

\section{References}

1. Ende-Verhaar YM, Cannegieter SC, Vonk Noordegraaf A, Delcroix M, Pruszczyk P, Mairuhu AT, et al. Incidence of chronic thromboembolic pulmonary hypertension after acute pulmonary embolism: a contemporary view of the published literature. Eur Respir J. 2017;49.

2. Sakuma M, Nakamura M, Yamada N, Ota S, Shirato K, Nakano T, et al. Venous thromboembolism: deep vein thrombosis with pulmonary embolism, deep vein thrombosis alone, and pulmonary embolism alone. Circ J. 2009;73:305-9.

3. Gall H, Hoeper MM, Richter MJ, Cacheris W, Hinzmann B, Mayer E. An epidemiological analysis of the burden of chronic thromboembolic pulmonary hypertension in the USA, Europe and Japan. Eur Respir Rev. 2017;26.

4. Lang IM, Pesavento R, Bonderman D, Yuan JXJ. Risk factors and basic mechanisms of chronic thromboembolic pulmonary hypertension: a current understanding. Eur Respir J. 2013;41:462-8.

5. Mayer E, Jenkins D, Lindner J, D’Armini A, Kloek J, Meyns B, et al. Surgical management and outcome of patients with chronic thromboembolic pulmonary hypertension: results from an international prospective registry. J Thorac Cardiovasc Surg. 2011;141:702-10.

6. Delcroix M, Kerr K, Fedullo P. Chronic thromboembolic pulmonary hypertension. epidemiology and risk factors. Ann Am Thorac Soc. 2016;13:S201-6.

7. Nakamura M, Okada O, Sakuma M, Nakanishi N, Miyahara Y, Yamada N, et al. Incidence and clinical characteristics of chronic pulmonary thromboembolism in Japan compared with acute pulmonary thromboembolism: results of a multicenter registry of the Japanese Society of Pulmonary Embolism Research. Circ J. 2002;66:257-60.

8. Madani MM, Auger WR, Pretorius V, Sakakibara N, Kerr KM, Kim NH, et al. Pulmonary endarterectomy: recent changes in a single institution's experience of more than 2,700 patients. Ann Thorac Surg. 2012;94:97-103; discussion 103 .

9. Bonderman D, Skoro-Sajer N, Jakowitsch J, Adlbrecht C, Dunkler D, Taghavi S, et al. Predictors of outcome in chronic thromboembolic pulmonary hypertension. Circulation. 2007;115:2153-8.

10. Pepke-Zaba J, Delcroix M, Lang I, Mayer E, Jansa P, Ambroz D, et al. Chronic thromboembolic pulmonary hypertension $(\mathrm{CTEPH})$ : results from an international prospective registry. Circulation. 2011;124:1973-81.

11. Ghofrani HA, D’Armini AM, Grimminger F, Hoeper MM, Jansa P, Kim NH et al. Riociguat for the treatment of chronic thromboembolic pulmonary hypertension. N Engl J Med. 2013;369:319-29.

12. Mizoguchi H, Ogawa A, Munemasa M, Mikouchi H, Ito H, Matsubara H. Refined balloon pulmonary angioplasty for inoperable patients with chronic thromboembolic pulmonary hypertension. Circ Cardiovasc Interv. 2012;5:748-55.

13. Lang I, Meyer BC, Ogo T, Matsubara H, Kurzyna M, Ghofrani HA, et al. Balloon pulmonary angioplasty in chronic thromboembolic pulmonary hypertension. Eur Respir Rev. 2017;26.

14. Tsugu T, Murata M, Kawakami T, Minakata Y, Kanazawa H, Kataoka M, et al Changes in right ventricular dysfunction after balloon pulmonary angioplasty in patients with chronic thromboembolic pulmonary hypertension. Am J Cardiol. 2016;118:1081-7.

15. Yamasaki Y, Nagao M, Abe K, Hosokawa K, Kawanami S, Kamitani T, et al. Balloon pulmonary angioplasty improves interventricular dyssynchrony in patients with inoperable chronic thromboembolic pulmonary hypertension: a cardiac MR imaging study. Int J Cardiovasc Imaging. 2017;33:229-39.

16. Ogawa A, Satoh T, Fukuda T, Sugimura K, Fukumoto Y, Emoto N, et al Balloon pulmonary angioplasty for chronic thromboembolic pulmonary hypertension: results of a multicenter registry. Circ Cardiovasc Qual Outcomes. $2017 ; 10$.

17. Olsson KM, Wiedenroth CB, Kamp JC, Breithecker A, Fuge J, Krombach GA et al. Balloon pulmonary angioplasty for inoperable patients with chronic thromboembolic pulmonary hypertension: the initial German experience. Eur Respir J. $2017 ; 49$.

18. Skoro-Sajer N, Gerges C, Gerges M, Panzenböck A, Jakowitsch J, Kurz A, et al Usefulness of thrombosis and inflammation biomarkers in chronic thromboem bolic pulmonary hypertension-sampling plasma and surgical specimens. J Heart Lung Transplant. 2018;37:1067-74. 
19. Mahmud E, Madani MM, Kim NH, Poch D, Ang L, Behnamfar O, et al. Chronic thromboembolic pulmonary hypertension: evolving therapeutic approaches for operable and inoperable disease. J Am Coll Cardiol. 2018;71: 2468-86.

20. Thistlethwaite PA, Mo M, Madani MM, Deutsch R, Blanchard D, Kapelanski DP, et al. Operative classification of thromboembolic disease determines outcome after pulmonary endarterectomy. J Thorac Cardiovasc Surg. 2002;124:1203-11.

21. "2015 ESC/ERS guidelines for the diagnosis and treatment of pulmonary hypertension. The joint task force for the diagnosis and treatment of pulmonary hypertension of the European Society of Cardiology (ESC) and the European Respiratory Society (ERS)." Nazzareno Galie, Marc Humbert, Jean-Luc Vachiery, Simon Gibbs, Irene Lang, Adam Torbicki, et alGerald Simonneau, Andrew Peacock, Anton Vonk Noordegraaf, Maurice Beghetti, Ardeschir Ghofrani, Miguel Angel Gomez Sanchez, Georg Hansmann, Walter Klepetko, Patrizio Lancellotti, Marco Matucci, Theresa McDonagh, Luc A. Pierard, Pedro T. Trindade, Maurizio Zompatori and Marius Hoeper. Eur Respir J 2015; 46: 903-975. Eur Respir J. 2015;46: 1855-6.

22. Garvey W. Modified elastic tissue-masson trichrome stain. Stain Technol. 1984; 59:213-6.

23. Alibay Y, Beauchet A, El Mahmoud R, Brun-Ney D, Alexandre JA, Benoit MO, et al. Analytical correlation between plasma N-terminal pro-brain natriuretic peptide and brain natriuretic peptide in patients presenting with dyspnea. Clin Biochem. 2004:37:933-6.

24. Lang IM, Simonneau G, Pepke-Zaba JW, Mayer E, Ambrož D, Blanco I, et al. Factors associated with diagnosis and operability of chronic thromboembolic pulmonary hypertension. A case-control study. Thromb Haemost. 2013;110:83-91.

25. Lang IM, Madani M. Update on chronic thromboembolic pulmonary hypertension. Circulation. 2014;130:508-18.

26. Kumasaka N, Sakuma M, Shirato K. Incidence of pulmonary thromboembolism in Japan. Jpn Circ J. 1999;63:439-41.
27. Kitamukai O, Sakuma M, Takahashi T, Kagaya Y, Watanabe J, Shirato K. Incidence and characteristics of pulmonary thromboembolism in Japan 2000. Intern Med. 2003;42:1090-4.

28. Tanabe N, Kimura A, Amano S, Okada O, Kasahara Y, Tatsumi K, et al. Association of clinical features with HLA in chronic pulmonary thromboembolism. Eur Respir J. 2005;25:131-8.

29. Guerin L, Couturaud F, Parent F, Revel MP, Gillaizeau F, Planquette B, et al. Prevalence of chronic thromboembolic pulmonary hypertension after acute pulmonary embolism. Prevalence of CTEPH after pulmonary embolism. Thromb Haemost. 2014;112:598-605.

30. Bonderman D, Jakowitsch J, Adlbrecht C, Schemper M, Kyrle PA, Schönauer V, et al. Medical conditions increasing the risk of chronic thromboembolic pulmonary hypertension. Thromb Haemost. 2005;93:512-6.

31. Friedman SE, Andrus BW. Obesity and pulmonary hypertension: a review of pathophysiologic mechanisms. J Obes. 2012;2012:505274.

32. Quarck R, Wynants M, Verbeken E, Meyns B, Delcroix M. Contribution of inflammation and impaired angiogenesis to the pathobiology of chronic thromboembolic pulmonary hypertension. Eur Respir J. 2015;46:431-43.

33. Bonderman D, Jakowitsch J, Redwan B, Bergmeister H, Renner MK, Panzenböck H, et al. Role for staphylococci in misguided thrombus resolution of chronic thromboembolic pulmonary hypertension. Arterioscler Thromb Vasc Biol. 2008;28:678-84.

34. Skoro-Sajer N, Marta G, Gerges C, Hlavin G, Nierlich P, Taghavi S, et al. Surgical specimens, haemodynamics and long-term outcomes after pulmonary endarterectomy. Thorax. 2014;69:116-22.

35. Zhang R, Brennan ML, Fu X, Aviles RJ, Pearce GL, Penn MS, et al. Association between myeloperoxidase levels and risk of coronary artery disease. JAMA. 2001;286:2136-42.

Key Words: chronic thromboembolic pulmonary hypertension, balloon pulmonary angioplasty, pulmonary embolism, thrombosis 
TABLE E1. Baseline characteristics in not-operated patients with CTEPH

\begin{tabular}{|c|c|c|c|}
\hline & \multicolumn{2}{|c|}{ Not-operated CTEPH patients ( $\mathrm{N}=20$ each) } & \multirow[b]{2}{*}{$P$ value } \\
\hline & Austria & Japan & \\
\hline Age, $y$ & $63(54-73)$ & $68(58-73)$ & $.44 *$ \\
\hline Female & 8 & 18 & - \\
\hline Height, $\mathrm{cm}$ & $175.4 \pm 8.7$ & $155.0 \pm 6.48$ & $<.001 \dagger$ \\
\hline Body weight, kg & $83 \pm 17$ & $58 \pm 10$ & $<.001 \dagger$ \\
\hline BMI, kg.m² & $27(23-30)$ & $23.7(22-27)$ & $.05^{*}$ \\
\hline Systemic pressure systolic, $\mathrm{mm} \mathrm{Hg}$ & $130.0 \pm 20.0$ & $124.0 \pm 25.0$ & $.43 \dagger$ \\
\hline Systemic pressure diastolic, $\mathrm{mm} \mathrm{Hg}$ & $70.0 \pm 11.0$ & $74.0 \pm 5.0$ & $.39 \dagger$ \\
\hline Systemic pressure, mean, $\mathrm{mm} \mathrm{Hg}$ & $93.0 \pm 13.0$ & $88.0 \pm 16.0$ & $.30 \dagger$ \\
\hline Pulmonary artery pressure systolic, $\mathrm{mm} \mathrm{Hg}$ & $72.0 \pm 20.0$ & $68.0 \pm 20.0$ & $.51 \dagger$ \\
\hline Pulmonary artery pressure diastolic, $\mathrm{mm} \mathrm{Hg}$ & $25.0 \pm 8.6$ & $22 \pm 5$ & $.17 \dagger$ \\
\hline Pulmonary artery pressure, mean, $\mathrm{mm} \mathrm{Hg}$ & $40.0 \pm 12.0$ & $40.0 \pm 9.2$ & $.99 \dagger$ \\
\hline Cardiac index, $\mathrm{L} / \mathrm{min} / \mathrm{m}^{2}$ & $2.6(2.5-3)$ & $2.5(2.2-3.5)$ & $.85^{*}$ \\
\hline Cardiac output, L/min & $5.0(4.5-6.2)$ & $4.1(4.6-5.4)$ & $.02 *$ \\
\hline Pulmonary vascular resistance, dyne.sec.cm ${ }^{-5}$ & $595 \pm 232$ & $609 \pm 228$ & $.84 \dagger$ \\
\hline $\mathrm{PaO}_{2}$ (room air), $\mathrm{mm} \mathrm{Hg}$ & $65.0 \pm 12.0$ & $66.0 \pm 12.0$ & $.87 \dagger$ \\
\hline Heart rate, beats/min & $72 \pm 14$ & $74 \pm 14$ & $.66 \dagger$ \\
\hline 6-MWD & $468 \pm 141$ & $274 \pm 110$ & $<.001 \dagger$ \\
\hline $\mathrm{VC}, \mathrm{L}$ & $3.8 \pm 1.2$ & $2.5 \pm 0.8$ & $<.001 \dagger$ \\
\hline$\% \mathrm{VC}$ & $92.0 \pm 18.0$ & $89.0 \pm 15.0$ & $.58 \dagger$ \\
\hline$\%$ FEV 1.0 & $77 \pm 11$ & $85 \pm 14$ & $.05 \dagger$ \\
\hline
\end{tabular}

Data are presented as mean \pm standard deviation or median (interquartile range), with differences in adjusted means and $95 \%$ confidence intervals. Nonparametric WilcoxonMann-Whitney $U$ test was used for non-normally distributed data and is indicated with * symbols, independent samples $t$ test for normally distributed data are indicated with $\dagger$ symbols. All $P$ values $(P<.05)$ are exploratory. $C T E P H$, Chronic thromboembolic pulmonary hypertension; $B M I$, body mass index, $\mathrm{PaO}_{2}$, arterial partial pressure of oxygen; 6-MWD, 6-minute walking distance; $V C$, vital capacity; FEV1.0, forced expiratory volume in 1 second. 
TABLE E2. Laboratory values in not-operated patients with CTEPH

\begin{tabular}{|c|c|c|c|}
\hline & \multicolumn{2}{|c|}{$\begin{array}{l}\text { Not-operated CTEPH } \\
\text { patients }(\mathrm{N}=20 \text { each })\end{array}$} & \multirow{2}{*}{$\begin{array}{c}P \\
\text { value }\end{array}$} \\
\hline & Austria & Japan & \\
\hline WBC, G/L & $7.1 \pm 2.9$ & $6.0 \pm 1.94$ & $.19 *$ \\
\hline $\mathrm{RBC}, 10 * 4 / \mu \mathrm{L}$ & $4.7 \pm 0.4$ & $4.3 \pm 0.6$ & $.02 *$ \\
\hline $\mathrm{Hb}, \mathrm{g} / \mathrm{dL}$ & $14.0 \pm 1.3$ & $13.0 \pm 1.8$ & $<.001 *$ \\
\hline Platelet, G/L & $236 \pm 75$ & $216 \pm 75$ & .40 \\
\hline Triglycerides, mg/dL & $111 \pm 44$ & $97 \pm 39$ & $.31 *$ \\
\hline Total cholesterol, mg/dL & $187.2 \pm 41.8$ & $206.7 \pm 37.7$ & $.13^{*}$ \\
\hline HDL cholesterol, mg/dL & $51.8 \pm 13.0$ & $65.0 \pm 13.0$ & $<.001 *$ \\
\hline LDL cholesterol, mg/dL & $149.0 \pm 158.0$ & $121.4 \pm 29.0$ & $.44 *$ \\
\hline GOT, U/L & $29(26-35)$ & $18(17-28)$ & $<.001 \dagger$ \\
\hline GPT, U/L & $29(21-55)$ & $16(13-30)$ & $.02 \dagger$ \\
\hline Albumin, g/dL & $4.0 \pm 0.4$ & $4.1 \pm .4$ & $.71^{*}$ \\
\hline Uric acid, mg/dL & $6.6 \pm 1.9$ & $5.7 \pm 1.7$ & $.01 *$ \\
\hline ProBNP, pg/mL & $1025(1278-2511)$ & $539(243-1387)$ & .61 \\
\hline D-dimer, $\mu \mathrm{g} / \mathrm{mL}$ & $0.60(0.3-0.5)$ & $0.77(0.6-5.6)$ & $.74 \dagger$ \\
\hline Creatinine, $\mathrm{mg} / \mathrm{dL}$ & $1.04 \pm 0.25$ & $0.88 \pm 0.60$ & $.26 *$ \\
\hline
\end{tabular}

Data are presented as mean \pm standard deviation or median (interquartile range), with differences in adjusted means and $95 \%$ confidence intervals. Nonparametric Wilcoxon-Mann-Whitney $U$ test was used for non-normally distributed data and is indicated with $\dagger$ symbols; independent samples $t$ test for normally distributed data are indicated with $*$ symbols. All $P$ values $(P<.05)$ are exploratory. CTEPH, Chronic thromboembolic pulmonary hypertension; $W B C$, white blood cells; $R B C$, red blood cells; $H b$, hemoglobin; $H D L$, high-density lipoprotein; $L D L$, low-density lipoprotein; $G O T$, glutamate oxaloacetate transaminase; GPT, glutamate pyruvate transaminase; ProBNP, pro-brain natriuretic peptide. 